\title{
POTENTIAL AREAS FOR THE FORMATION OF ECOLOGICAL CORRIDORS BETWEEN REMNANTS OF ATLANTIC FOREST ${ }^{1}$
}

João Flávio Costa dos Santos ${ }^{2 *}$, Bruno Araujo Furtado de Mendonça ${ }^{3}$, Emanuel José Gomes de Araújo ${ }^{3}$, Rafael Coll Delgado ${ }^{4}$ and José Marinaldo Gleriani ${ }^{5}$

\footnotetext{
${ }^{1}$ Received on 23.04.2015 accepted for publication on 02.09.2016.

${ }^{2}$ Universidade Federal de Viçosa, Programa de Pós-Graduação em Ciência Florestal, Viçosa, MG - Brasil. E-mail: <joao.flavio@ufv.br>.

${ }^{3}$ Universidade Federal Rural do Rio de Janeiro, Instituto de Florestas, Departamento de Silvicultura, Seropédica, RJ - Brasil. E-mail: <brunoafmendonca@gmail.com>and <ejgaraujo@gmail.com>.

${ }^{4}$ Universidade Federal Rural do Rio de Janeiro, Instituto de Florestas, Departamento de Ciências Ambientais, Seropédica, RJ - Brasil. <rafaelcolldelgado32@gmail.com>.

${ }^{5}$ Universidade Federal de Viçosa, Departamento de Engenharia Florestal, Viçosa, MG - Brasil. E-mail: <gleriani@ufv.br>.

*Corresponding author.
}

\begin{abstract}
In Brazil, the remaining areas of Atlantic Forest are intensely fragmented. The connection of forest fragments through ecological corridors is an important step in biodiversity conservation. Certain areas are more resilient, and in those areas, natural forest regeneration, for example, can be encouraged. The aim of this study was to identify areas of greater resilience in order to support the connection of Atlantic Forest fragments with ecological corridors. Forest fragments in the municipality of Paraíba do Sul, in the state of Rio de Janeiro, were mapped using the supervised maximum likelihood classification of an Operational Land Imager (OLI)/Landsat-8 sensor image. Next, we analyzed the influence of terrain attributes (aspect, incident solar radiation, slope, and curvature profile) on natural regeneration. The areas with the greatest potential to achieve natural regeneration and to form ecological corridors were indicated through fuzzy membership functions. Within Paraíba do Sul, $31 \%$ of the territory is covered by vegetation in different stages of regeneration. Recordings were made of 1,251 forest fragments in a middle or advanced stage of regeneration. These fragments are usually situated in the southeast, south, and southwest aspects, in areas that receive the least amount of global solar radiation $\left(\mathrm{Wh} \cdot \mathrm{m}^{-2}\right)$ per year, and on slopes with an angle of inclination greater than $20 \%$. The adjustment of fuzzy functions identified $17,327.5$ ha with a tendency to recover, and which are therefore strategic areas in the development of ecological corridors.
\end{abstract}

Keywords: Resilience; Forest fragmentation; Remote sensing.

\section{ÁREAS POTENCIAIS À FORMAÇÃO DE CORREDORES ECOLÓGICOS ENTRE REMANESCENTES DE MATA ATLÂNTICA}

\begin{abstract}
RESUMO - No Brasil, a Mata Atlântica remanescente é intensamente fragmentada. A conexão de fragmentos florestais através de corredores ecológicos é um passo importante para a conservação da biodiversidade. Determinados locais da paisagem têm maior resiliência e a regeneração natural, por exemplo, pode ser favorecida. Neste trabalho fragmentos florestais remanescentes de Mata Atlântica, no municipio de Paraíba do Sul, RJ, foram mapeados. Utilizou-se a classificação supervisionada, por máxima verossimilhança, de uma imagem do sensor OLI/Landsat-8; analisou-se a influência de atributos do terreno (face de exposição, radiação solar, declividade e perfil de curvatura) na regeneração natural; $e$, as áreas com maior potencial para condução da regeneração natural e formação de corredores ecológicos foram indicadas através de pertinência fuzzy. Paraíba do Sul tem $31 \%$ do território coberto por vegetação em diferentes estágios de regeneração. Foram contabilizados 1.251 fragmentos florestais em estágio médio ou avançado de
\end{abstract}


regeneração situados, preferencialmente, nas vertentes sudeste, sul e sudoeste, as quais recebem menor quantidade de radiação solar global (Wh. $\mathrm{m}^{-2}$ ) por ano, e em declividades superiores a 20\%. O ajuste de funções fuzzy permitiu identificar 17.327,5 ha de território que tendem a facilitar a recuperação florestal e são, portanto, áreas estratégicas para a formação de corredores ecológicos.

Palavras-chave: Resiliência; Fragmentação florestal; Sensoriamento remoto.

\section{INTRODUCTION}

The Brazilian Atlantic Forest is one of the richest ecosystems on the planet in terms of biodiversity and also one of the most devastated. These characteristics qualify this biome as a global biodiversity hotspot (MEYERS et al., 2000). Only $12.5 \%$ of the original forest formation remains (FUNDAÇÃO SOS MATA ATLÂNTICA, 2014), which is now mostly composed of forest fragments with reduced area and increased isolation (RIBEIRO et al., 2009).

The area of each fragment dictates the species richness and abundance as well as the functionality of the ecosystem (METZGER, 2001). In addition to causing local extinctions, fragmentation can have longterm effects on the populations through changes in ecological processes such as pollination, predation, territorial behavior, and eating habits (RANTA et al., 1998).

One of the measures adopted to minimize the effects of fragmentation is the promotion of forest fragment connections through ecological corridors (METZGER et al., 2009). The ecological corridors are homogeneous areas of a landscape unit distinguished from neighboring units due to a linear design (METZGER, 2001).

Variations in topographical conditions engender distinctive degrees of resilience, thus affecting the formation of the landscape. After a natural or manmade disturbance, natural forest regeneration differs according to terrain conditions such as elevation, inclination, and slope orientation (CERDÀ et al., 1995; MARQUES et al., 2004; SILVERIA \& SILVA, 2010).

By identifying the behavior of the vegetation in the fragmented landscape, one can define the most conducive conditions in which to establish recovery projects (AMICI et al., 2010; SARTORI et al., 2012). However, recent work using geographic information systems (GIS) that map potential areas to form ecological corridors have not taken into consideration the landscape's level of resilience (AMICI et al., 2010; SARTORI et al., 2012; FERRATI et al., 2013).
This study sought to identify areas of greater resilience, with the objective of promoting the connection of Atlantic Forest fragments through ecological corridors.

\section{MATERIALAND METHODS}

\subsection{Study area}

The municipality of Paraíba do Sul, with the following central geographic coordinates, was the designated study area: latitude $22^{\circ} 09^{\prime} 43^{\prime \prime} \mathrm{S}$ and longitude $43^{\circ} 17^{\prime} 34^{\prime \prime} \mathrm{W}$. The region has an area of $580.52 \mathrm{~km}^{2}$ and is located in the watershed of the river Paraíba do Sul, in the south-central region of the state of Rio de Janeiro. According to the Köppen climate classification map for Brazil (ALVARES et al., 2013) the municipality has a humid subtropical climate with dry winter and hot summer (Cwa). Rainy seasons alternate with dry seasons and the greatest amount of rainfall is recorded in the summer (AGEVAP, 2013). In general, two forest formations of the Atlantic Forest biome occur in the municipality: the seasonal semideciduous forest in the northwest region of the municipality, and the dense ombrophilous forest in the south (IBGE, 1993). The SOS Mata Atlântica Foundation (2014) estimates that the municipality, which was once completely covered by the Atlantic Forest, now retains only forest fragments that represent $8 \%$ of the territory $(4,352$ ha $)$.

\subsection{Identification of forest fragments}

To identify forest fragments present in Paraíba do Sul, a supervised maximum likelihood classification (MaxLike) was conducted using ArcGIS 10.1 software. The classification employed an image from the Landsat8 orbital platform, which operates with the Operational Land Imager (OLI) and the Thermal Infrared Sensor (TIRS) image sensors. The image used the path/row $217 / 75$ from July 14,2014 . It was originally acquired in the UTM Zone 23N, Projection/Datum WGS1984, and redesigned for the UTM Zone 23S, Projection/ Datum SIRGAS 2000. 
A spatial resolution of $15 \mathrm{~m}$ for bands 1 to 8 was achieved by fusing the multispectral bands with the panchromatic band. The Normalized Difference Vegetation Index (NDVI) (ROUSE et al., 1974) and the first and second main components, as well as the nine bands in the visible spectrum, were included to assist in the classification.

Training samples were taken (10 to 12 pixels) so that a minimum of 750 pixels were sampled for each of the following classes: water, urban area, absence of forest cover (pasture, agriculture and bare soil), early stage of regeneration, and middle or advanced stage of regeneration. The samples for the regeneration classes were collected through field recognition and, for the other classes, samples were collected with the aid of Google Earth. To differentiate the regeneration stages, mainly the expanse of the vegetation and the species composition were considered, as established by CONAMA (BRASIL, 1994). However, due to the difficulties in distinguishing the middle from the advanced stage of regeneration, these two categories were combined into a single class.

After completing the classification process, the generated raster was post-processed to remove isolated sets of 10 pixels. From the results of classification, the raster file was converted into a vector format.

In addition to the training samples, 15 validation samples were collected per class to evaluate the quality of the classification. These samples were collected in a similar manner as the training samples; special attention was taken to avoid overlapping. Classification accuracy was evaluated by the kappa and conditional kappa coefficients (CONGALTON, 1991), which were calculated from the confusion matrix representing the classified image and validation samples.

\subsection{Obtaining terrain variables}

The digital elevation model (DEM) of the study area was obtained from the Brazilian Institute of Geography and Statistics (IBGE) website at a scale of 1:25,000 and spatial resolution of $20 \mathrm{~m}$. This DEM was generated from altitude extraction algorithms by correlation of aerial photographs obtained from an aerial survey. From this DEM were derived topographic variables of slope (\%), curvature profile, aspect (degrees), and global solar radiation $\left(\mathrm{Wh} \cdot \mathrm{m}^{-2}\right)$.

The class of aspect, distributed between $0^{\circ}$ and $360^{\circ}$, increases clockwise and can be organized as follows: north $\left(337.5^{\circ}\right.$ to $\left.22.49^{\circ}\right)$, northeast $\left(22.5^{\circ}\right.$ to $\left.67.49^{\circ}\right)$, east $\left(67.5^{\circ}\right.$ to $\left.112.49^{\circ}\right)$, southeast $\left(112.5^{\circ}\right.$ to $\left.157.49^{\circ}\right)$, south $\left(157.5^{\circ}\right.$ to $\left.202.49^{\circ}\right)$, southwest $\left(202.5^{\circ}\right.$ to $\left.247.49^{\circ}\right)$, west $\left(247.5^{\circ}\right.$ to $\left.292.49^{\circ}\right)$, and northwest $\left(292.5^{\circ}\right.$ to $\left.337.49^{\circ}\right)$.

The raster file of slope was reclassified according to the criteria of the Brazilian Agricultural Research Corporation (EMBRAPA, 1979) as follows: plain terrain (0-2.99\%); slightly undulating (3-7.99\%); undulating (8-19.99\%); strongly undulating (20-44.99\%); mountainous (45-74.99\%); and rugged (>75\%).

According to Valeriano (2003), the vertical curvature refers to the convex or concave character of a terrain, when seen in profile. Theoretically, straight slopes have a null curvature value, concave slopes have positive values, and convex slopes have negative values. However, according to Valeriano, in practice, few of the hills that are considered rectilinear present strictly null curvatures; therefore, it is beneficial to adopt a tolerance range in this interpretation. Thus, in this work, values of a curvature profile between $-0.15<\mathrm{x}<0.15$ are considered rectilinear slopes. Concave slopes have values above this limit and convex slopes have values below this limit.

The calculation of the global solar radiation (Wh. $\mathrm{m}^{-2}$ ) was obtained for each day of 2013, based on the algorithm developed by Rich et al. (1994), and executed with the solar radiation tool. This simulation involves a raster representation that displays the apparent position of the sun, calculated based on the latitude of the study area, which varies according to the time of day and the day of the year.

\subsection{Use of fuzzy logic to identify areas of greatest resilience}

The maps of terrain attributes were converted to a vector format. Files of intersection between forest remnants and DEM derivatives were generated. Possible relationships between topographical conditions and the presence of fragments were analyzed. Then, the areas that tend to facilitate the presence of forest fragments in Paraíba do Sul were mapped. In this step, the free ArcSIE (Soil Interference Engine) extension was employed (SHI, 2013).

The ArcSIE software was developed to map soil classes and attributes through Rule-Based Reasoning

Revista Árvore, Viçosa-MG, v.40, n.5, p.803-813, 2016

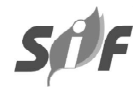


(RBR) or Case-Based Reasoning (CBR) (SHI, 2013). This is a useful extension for building soil-landscape models based on fuzzy logic.

In fuzzy sets, the elements are presented with varying degrees of adherence to a class. A membership function assigns values ranging from zero to one. This logic provides a natural way to deal with issues in which the source of uncertainty is the lack of well-defined criteria and not the presence of random variables (ZADEH, 1965).

The option rules editing (RBR) of ArcSIE was used to generate a fuzzy membership mapping that shows the class of the most suitable areas to form forest fragments. In ArcSIE, the creation of fuzzy membership mappings consists basically of three phases, represented by three functions (T, P, and E). Equation 1 describes how the knowledge of a given class (of soil or, in this case, of the suitability to form fragments) will be used in a process of RBR.

$$
\mathrm{S}_{i j, k}=T_{k_{g=1}}^{n}\left\{P_{c_{a=1}^{m}}^{m}\left[E_{c, a}\left(Z_{i j, a}, Z_{c, a}\right)\right]\right\}
$$

where: $S_{i j, k}$ is the fuzzy membership value at the $i j$ area for the class $k ; m$ is the number of environmental resources used for inference; $n$ is the number of instances for the class $k ; Z_{i j, a}$ is the value of the environmental resource in the position or pixel $(i j) ; Z_{c, a}$ is the ideal range of instance $c$ for the occurrence of class $\mathrm{k}$ in the function of the environmental characteristic $a$; $E$ is the function to assess the value of environmental resource optimization; $P$ is the function to assess the fuzzy membership at the instance level; and $T$ is the function to determine the value of the final fuzzy membership for the class on area $k(i j)$ based on all instances.
The ArcSIE allows the user to adjust the function $\boldsymbol{E}$ by choosing, among the types of curves available, the one that is most pertinent to represent the influence of the environmental variable in a class $k$. The value 1 is assigned when there is a $100 \%$ probability of occurrence of class $k$ (editable parameter V). The editable parameter $\mathrm{W}$ represents a $50 \%$ probability of occurrence of class $k$. The "bell" function is useful when the derivative of the terrain influences class $\mathrm{k}$ in a range between $\mathrm{V} 1$ and V2 values. The "S" function is applicable only when the values greater than V1 explain the class, and in the case of the opposite situation, the function " $Z$ " exists.

It is necessary to load the matrix files of the terrain derivatives that influence class $k$ in order to edit the rules. For each variable, the boundaries that favor the presence of forest fragments were defined-which basically equals the curves adjustment. After adjusting the functions, the fuzzy membership map indicating the areas with higher chances of successful ecological corridor formations via conduction of natural regeneration was obtained.

\section{RESULTS}

Table 1 presents the kappa conditional (by class) and kappa (general) coefficients that assess the quality of the classification supervised by the adopted algorithm (MaxLike).

The supervised classification has shown that most of the municipal territory $\left(325.67 \mathrm{~km}^{2}\right)$ is represented by the absence of forest cover category. Urban areas total $66.20 \mathrm{~km}^{2}$ and water bodies occupy $6.31 \mathrm{~km}^{2}$, of which the Paraíba do Sul River is the largest portion. The two classes of natural regeneration combined represent about $31 \%\left(182.32 \mathrm{~km}^{2}\right)$ of the area of the

Table 1 - Kappa index and interpretation of the supervised classification of the OLI/Landsat-8 image for the municipality of Paraíba do Sul/RJ.

Tabela 1 -Índice Kappa e interpretação da classificação supervisionada da imagem OLI/Landsat-8 para o município de Paraiba do Sul/RJ.

\begin{tabular}{|c|c|c|c|}
\hline \multirow[t]{2}{*}{ Class } & \multicolumn{3}{|c|}{ Conditional Kappa } \\
\hline & Kappa & Var. & Interpretation* \\
\hline Water & 1.00 & 0 & Excellent \\
\hline Absence of Forest Cover & 0.92 & $8.2 .10^{-5}$ & Excellent \\
\hline Urban Area & 0.80 & $6.8 .10^{-4}$ & Very good \\
\hline Regeneration-Middle or Advanced Stage & 0.92 & $1.3 .10^{-4}$ & Excellent \\
\hline Regeneration-Early Stage & 0.96 & $1.1 .10^{-4}$ & Excellent \\
\hline General Index & 0.89 & $6.010^{-5}$ & Excellent \\
\hline
\end{tabular}

* Interpretation based on the parameters of Landis and Kock (1977).

Revista Árvore, Viçosa-MG, v.40, n.5, p.803-813, 2016 
municipality, of which $94.05 \mathrm{~km}^{2}$ are composed of forest in the early stage of growth and $88.17 \mathrm{~km}^{2}$ are forests in the middle or advanced stages. It was possible to account for 1,519 fragments in the early stage and 1,251 in the middle or advanced stages of natural regeneration.

From the information plans on aspect and global solar radiation, it is possible to observe a relationship between the direction of exposure and amount of solar radiation received. Numerically, the 2013 data establish that the annual average solar radiation was $1.64 \mathrm{MWh} \cdot \mathrm{m}^{-2}$ on plain areas; $1.68 \mathrm{MWh} \cdot \mathrm{m}^{-2}$ on slopes facing north; $1.66 \mathrm{MWh} \cdot \mathrm{m}^{-2}$ in the northeast; $1.62 \mathrm{MWh} \cdot \mathrm{m}^{-2}$ in the east; $1.57 \mathrm{MWh} \cdot \mathrm{m}^{-2}$ in the southeast; $1.55 \mathrm{MWh} \cdot \mathrm{m}^{-2}$ in the south; $1.57 \mathrm{MWh} \cdot \mathrm{m}^{-2}$ in the southwest; 1.62 $\mathrm{MWh} \cdot \mathrm{m}^{-2}$ in the west; and $1.66 \mathrm{MWh} \cdot \mathrm{m}^{-2}$ in the northwest hills. Taking the averages into consideration, there is a difference of $129,715 \mathrm{MWh} \cdot \mathrm{m}^{-2}$ between the surface that receives the least (south) and the one that receives the greatest (north) amount of global solar radiation.

Figure 1 illustrates the relationships between the examined environmental variables and the number of forest fragments in early and middle or advanced stages of natural regeneration. The terrain variables that most contributed to the development of forest fragments into more advanced classes of regeneration were slope, aspect, and solar radiation. Therefore, these variables were used to delimit areas in the landscape that have greater resilience through fuzzy membership functions (Figure 2).

According to the results obtained, greater inclinations favor the presence of forest fragments. Thus, for this variable, the "S" function is considered the most appropriate. Since forest fragments in middle or advanced stages of regeneration are typically in southeast, south, and southwest (i.e., $112.5^{\circ}$ to $247.49^{\circ}$ ) aspects, the "bell" function has been chosen for the aspect criterion. For the global solar radiation criterion, estimated through the solar analyst algorithm proposed by Rich et al. (1994), it was found that smaller annual quantities favor the presence of forest fragments in middle or advanced stages and, therefore, the "Z" function was most appropriate.

The $\mathrm{V}$ and $\mathrm{W}$ editable parameters values (Figure 2 ), were employed on the basis of the adopted division of regeneration classes. For solar radiation, the superior value of radiation in which fragments in a middle or advanced stage of forest regeneration have been found was employed as the $100 \%$ probability limit (V2) and the top value for fragments in the early stage of regeneration was considered 50\% (W2).

The fuzzy membership map allowed for the identification of areas with environmental conditions that favor the evolution of forest fragments, i.e., areas with greater resilience (Figure 3). Excluding the urbanized region and areas already occupied by fragments in a middle or advanced stage of regeneration (Table 2), areas totalizing $17,327.5$ ha present environmental variables with great recovery possibility (fuzzy membership greater than $81 \%$ ) and can be recommended for the formation of ecological corridors.

\section{DISCUSSION}

Kappa conditional indexes were classified as very good for the urban areas and excellent for the other classes. The general kappa index was 0.89 and was regarded, therefore, as excellent (LANDIS \& KOCK, 1977). These results point to a reliable classification through the adopted methodology. Thus, the classified image was useful for mapping forest remnants into two regeneration stages (early stage and middle or advanced stage).

The results of this study differ from those presented by the SOS Mata Atlântica Foundation (2014) on areas of forest remnants. The atlas of the foundation points to $8 \%$ of remaining vegetation while this study suggests $15 \%$. Differences in the methodologies adopted explain these results. The SOS Mata Atlântica Foundation (2014) mapped only fragments greater than 3 ha and in an advanced stage of regeneration. In this study, all of the fragments were taken into consideration and the intermediate and advanced stages of regeneration were combined. In addition, the NDVI and the main components 1 and 2 were applied to assist in obtaining the spectral signature of the classes.

In the Southern Hemisphere, the apparent path of the sun undergoes a declination to the north. This declination reaches its maximum value $\left(+23.45^{\circ}\right)$ at the winter solstice (approximately June 22), its minimum value $\left(-23.45^{\circ}\right)$ in summer (December 22 ), and is null when the sun's declination presents a value that is equal to the latitude of the studied point (the zenith). This is why, in the Southern Hemisphere, the northfacing areas receive more energy compared to those facing south, especially in winter (GANDOLFI, 2000;

Revista Árvore, Viçosa-MG, v.40, n.5, p.803-813, 2016

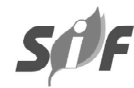


Early Stage
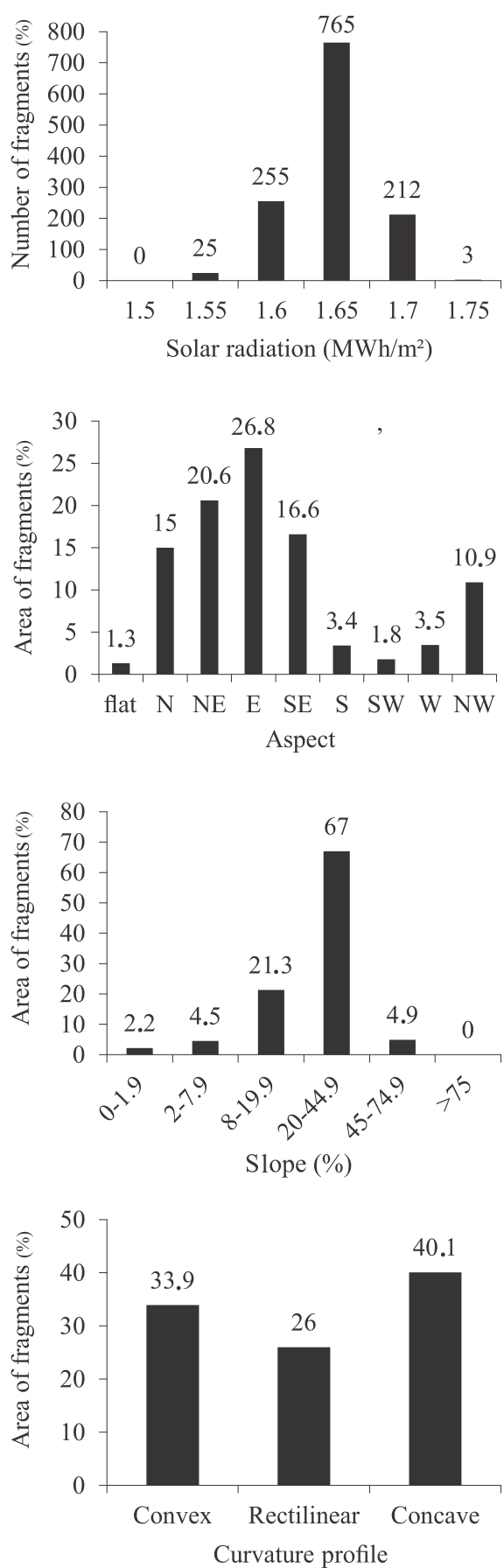

Middle or Advanced Stage
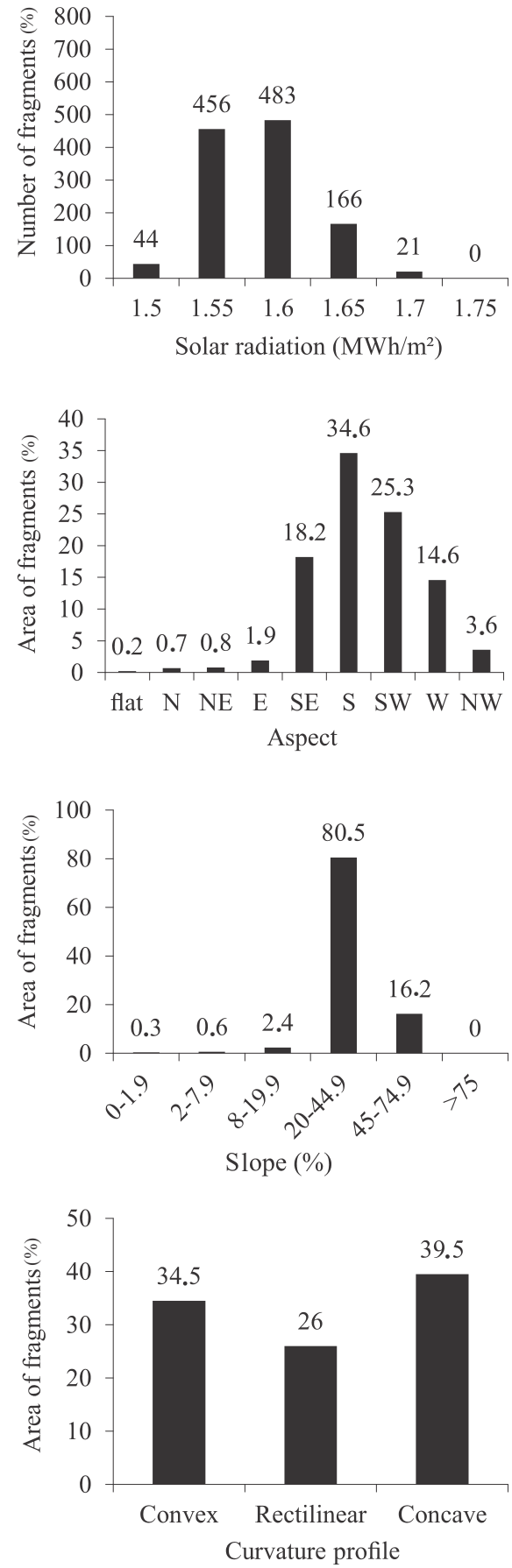

Figure 1 - Environmental variations in forest fragments in early and middle or advanced stages of natural regeneration in the municipality of Paraíba do Sul/RJ.

Figura 1 - Variações ambientais em fragmentos florestais nos estágios inicial e médio ou avançado de regeneração natural no município de Paraíba do Sul/RJ.

Revista Árvore, Viçosa-MG, v.40, n.5, p.803-813, 2016 
MACHADO, 2009). These differences in local energy intake influence the terrain's resilience. Marques et al. (2004) found that the south-facing slopes are more resilient. Cortines et al. (2011) concluded that the floristic composition of a dense ombrophilous forest changes according to the face of exposure, and in drier slopes (facing north) species of semideciduous forest occur.

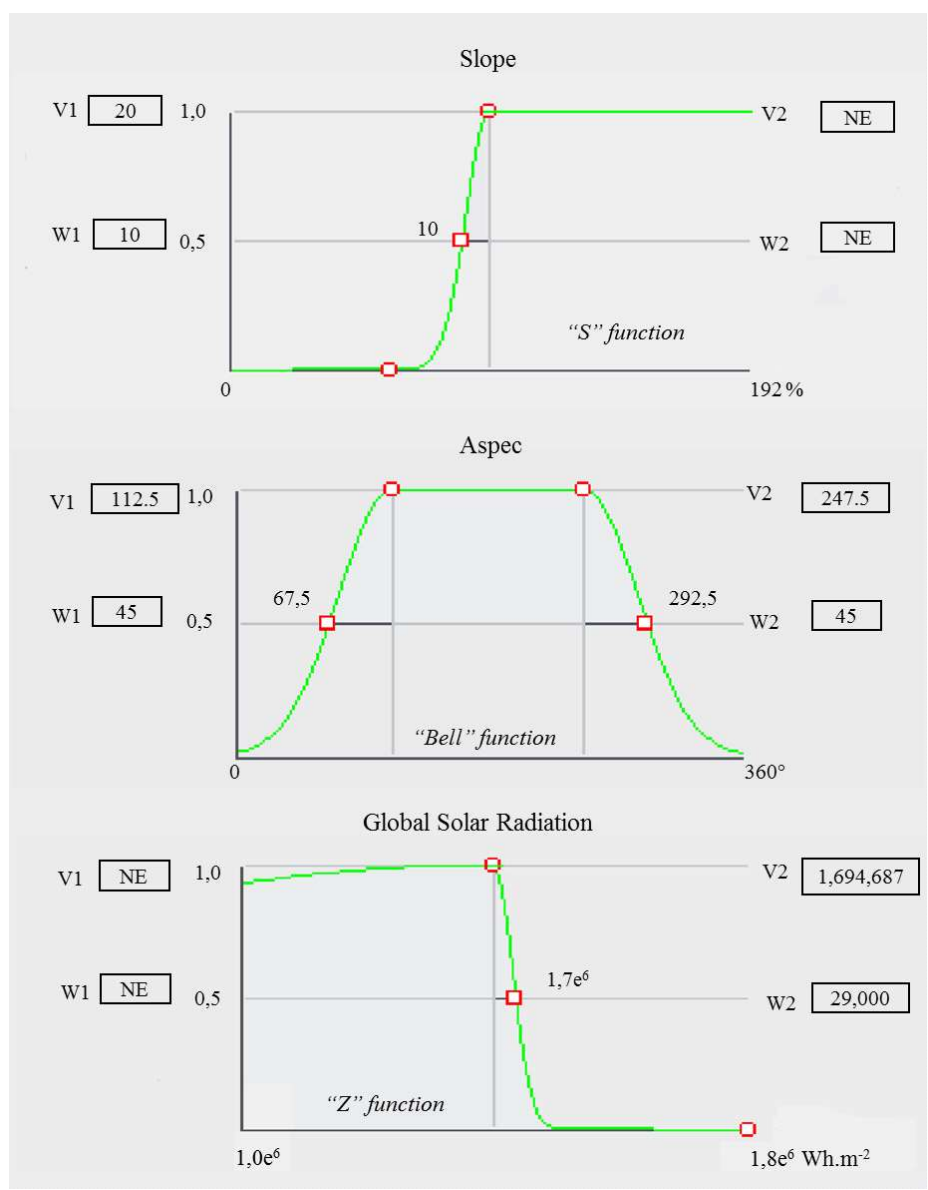

Figure 2 - Curve adjustments in ArcSIE for the ground derivatives that influence the presence of forest fragments in middle or advanced stages of regeneration in the municipality of Paraíba do Sul/RJ. NE - Non-editable Parameters.

Figura 2 - Ajuste de curvas no ArcSIE para derivadas do terreno que exercem influência na presença de fragmentos florestais em estágio médio ou avançado de regeneração no município de Paraíba do Sul,/RJ.NE - Parâmetros Não Editáveis.

Table 2 - Area occupied, presence of urban area, and forest fragments in each class of fuzzy membership for the formation of ecological corridors in the municipality of Paraíba do Sul/RJ.

Tabela 2 - Área ocupada, presença de área urbanizada e fragmentos florestais em cada classe de pertinência fuzzy para formação de corredores ecológicos no município de Paraíba do Sul/RJ.

\begin{tabular}{cccc}
\hline Membership Class(\%) & Class Area(ha) & Urban Area(ha) & Area Occupied by Fragments (ha) \\
\hline $0-20$ & $19,269.00$ & $2,516.40$ & 260.20 \\
$21-40$ & $7,922.92$ & 924.28 & 272.92 \\
$41-60$ & $5,641.52$ & 537.76 & 331.08 \\
$61-80$ & $5,266.40$ & 424.36 & 477.68 \\
$81-100$ & $26,183.10$ & $1,113.92$ & $7,741.68$ \\
\hline
\end{tabular}




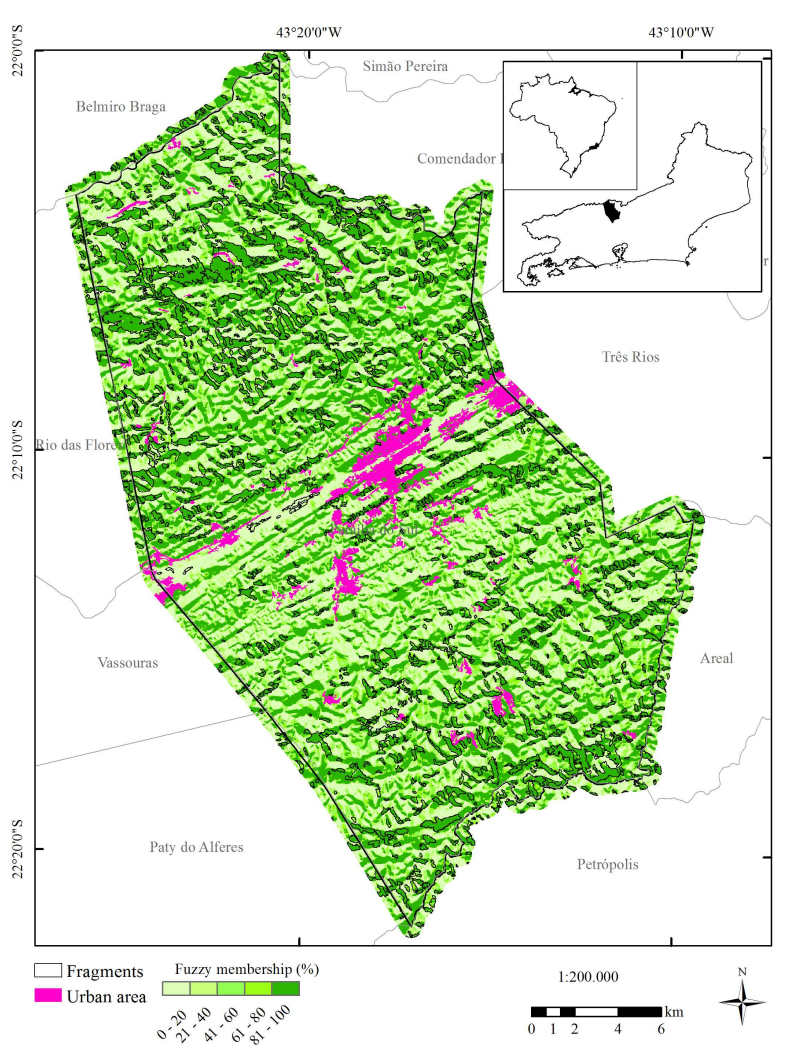

Figure 3 - Fuzzy membership map identifying the most suitable areas for the formation of ecological corridors in the municipality of Paraíba do Sul/RJ.

Figura 3-Mapa de pertinência fuzzy identificando as áreas mais aptas à formação de corredores ecológicos no município de Paraíba do Sul/RJ.

In the Northern Hemisphere the apparent motion of the sun is the reverse, and south-facing areas are less resilient. Cerdà et al. (1995) concluded that in the southeast of Spain, slopes facing south have slower regeneration rates and greater water stress. These authors also concluded that the soils of these surfaces have less stable aggregates and suffer greater erosion.

The results obtained in this study indicate that the amount of energy received by a hill interferes with the evolution of forest fragments in more advanced regeneration classes. In this sense, the surfaces receiving less global radiation per year are concentrated with more fragments in medium or advanced stages of regeneration.

The results obtained by Silveira and Silva (2010) of the interactions between vegetation cover dynamics and aspect in the Paquequer River basin in Teresópolis, Rio de Janeiro, are similar with the results of this study. These authors found that the forest fragments evolved to advanced stages of forest regeneration, preferably on south-facing slopes, and the favorable characteristics of the aspect presented relevance only to regeneration processes in advanced stages but not for those in early stages. Silveira and Silva (2010) suggest that this is due to the ability of pioneering vegetation classes to support varied conditions, while the climax vegetation and those in an advanced stage of succession are more selective about humidity and solar incidence.

Field observations lead to another hypothesis in this study area. In the municipality, burnings are a common practice, usually adopted to replace a dry pasture with new grass that comes with the onset of the rainy season. It is known that surfaces receiving greater amounts of solar radiation are less humid, which encourages the spread of fire (RIBEIRO et al., 2008). Therefore, even though the Atlantic Forest presents a high renewal rate (METZGER et al., 2009), fire is one of the factors that hinders the evolution of natural regeneration, mainly on drier aspects.

The results found in this work for the slope criterion also resemble those by Silveira and Silva (2010). The authors found that both the initial and advanced classes of regeneration follow the same pattern of inclination distribution and that deforestation is higher in less inclined areas (up to $20 \%$ ), where anthropic use is easier.

The slope generates gradients of moisture in the soil between the top and the base of a slope, favoring the transport of soil particles along a profile, and interferes with the vertical organization of the canopy, causing variations in the angles of penetration and distribution of light within forests (GANDOLFI, 2000). The slope, depending on the location's latitude, contributes to an increase or decrease in the exposure of the surface to sunlight throughout the year (MACHADO et al., 2009). Therefore, for the study area, the higher the inclination, the greater the differences in received solar radiation.

In addition, since slopes facing south, southwest, and southeast in some regions near the Brazilian coast receive humid air masses from the ocean, there is a moisture gain in these areas. This extends the potential for resilience of such hills (MARQUES et al., 2004; CORTINES et al., 2011). 
Valeriano (2003) points out that the variable curvature profile is related to the processes of migration and the accumulation of water, minerals, and organic matter in the soil across the surface, provided by gravity. He also reports that, associated with slope exposure, the vertical curvature plays an important role in evapotranspiration and the resulting water balance. While this variable contributes to the generation of differences in the terrain, it showed no contribution to the development of forest fragment regeneration according to the adopted parameters.

Although it was developed to map soil classes and attributes, the ArcSIE extension in this work proved to be appropriate. It should be noted that in both situations landscape attributes are used to define a class, which are in this case the ecological corridors. The map of this scenario (Figure 3) allows the visualization of the most suitable areas to form ecological corridors. Since $85 \%$ of the area occupied by fragments in the middle or advanced stages of regeneration is inserted into portions of the landscape with fuzzy membership higher than $81 \%$, this map was also useful to prove the range of resilience in the landscape and to validate the adjustment of functions (Figure 2).

The connection of fragments is established as a facilitator of gene flow and therefore has great importance for the conservation of natural resources (METZGER et al., 2009; AMICI et al., 2010; SARTORI et al., 2012; FERRATI et al., 2013). According to Brazilian forest legislation, especially Federal Law No. 12,651 of May 25, 2012, every landowner is obligated to respect the Areas of Permanent Preservation (APP) and also to maintain on their property a Legal Reserve (LR) area. That same law provided that the location of the LR in the rural property should take into consideration the connection with other fragments. One of the ways to recover the APP and to form an LR is to conduct natural regeneration. In this sense, the present work considered the zoning of the entire municipality of Paraíba do Sul, indicating the most suitable areas in which to form forest fragments via natural regeneration that also respond more quickly to projects that recover degraded areas. According to Sartori et al. (2012), with regard to the prioritization of areas, spatialization represents one of the most efficient and cost-effective methods. Therefore, the observation of nature enabled the development of a theoretical model with practical applications, which will increase the chances of success in conservation actions adopted in the municipality of Paraíba do Sul, Rio de Janeiro, and the surrounding region.

\section{CONCLUSIONS}

In Paraíba do Sul, the fragments in middle or advanced stages of regeneration are most common on the south, southwest, and southeast aspects, with a slope higher than $20 \%$. These areas receive less global solar radiation per year and constitute strategic areas for natural regeneration. The adjustment of fuzzy logic functions allowed for the identification of $17,327.5$ ha in the study area that tend to facilitate forest recovery. Therefore, they are strategic areas for resource implementation and optimization and to carry out conservation programs such as the formation of ecological corridors.

\section{REFERENCES}

ALVARES, C.A.; STAPE, J.L.; SENTELHAS, P.C.; MORES, G.; LEONARDO, J.; SPAROVEK, G. Köppen's climate classification map for Brazil. Meteorolgische Zeitschrift, v.22, n. 6, p.711-728, 2013.

AMICI, V.; GERI, F.; BATTISTI, C. An integrated method to create habitat suitability models for fragmented landscapes. Journal for Nature Conservation, v. 18, n.3, p.215-223, 2010.

\section{ASSOCIAÇÃO PRÓ-GESTÃO DAS ÁGUAS DA BACIA HIDROGRÁFICADO RIO PARAÍBA DO SUL - AGEVAP. Plano regional de saneamento básico caracterização do município projeto aplicado de comunicação e mobilização social Paraíba do Sul. Taubaté: Vallenge Consultoria Projetos e Obras Ltda., 2013. 77p.}

BRASIL. Resolução CONAMA n ${ }^{\circ}$ 6, de 4 de maio de 1994. Estabelece definiçõos e parâmetros mensuráveis para análise de sucessão ecológica da Mata Atlântica no Rio de Janeiro. Diário Oficial da República Federativa do Brasil, Brasília, DF, de 30 de maio de 1994.

CONGALTON, R.G. A review of assessing the accuracy of classifications of remotely sensed data. Remote Sensing of Environment, v.37, n.1, p.35-46, 1991.

Revista Árvore, Viçosa-MG, v.40, n.5, p.803-813, 2016

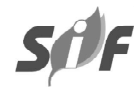


CORTINES, E.; PEREIRA, A.L.; SANTOS, P.R.O.; SANTOS, G.L.; VALCARCEL, R. Vegetação arbórea em vertentes com orientação norte e sul na Floresta Montana, Nova Friburgo-RJ.

Floresta e Ambiente, v.18, n.4, p.428-437, 2011.

CERDÀ, A.; IMESON, A.C.; CALVO, A. Fire and aspect induced differences on the erodibility and hydrology of soils at La Costera, Valencia, southeast Spain. Catena, v.24, n.4, p.289-304, 1995.

\section{EMPRESA BRASILEIRA DE PESQUISA} AGROPECUÁRIA - EMBRAPA. Serviço Nacional de Levantamento e Conservação de Solos.

Súmula da $10^{\mathrm{a}}$ Reunião Técnica de Levantamento de Solos. Rio de Janeiro: 1979. 83p.

FERRETTI, V.; POMARICO, S. An integrated approach for studying the land suitability for ecological corridors through spatial multicriteria evaluations. Environment, Development and Sustainability, v.15, n.3, p.859-885, 2013.

FUNDAÇÃO SOS MATA ATLÂNTICA. Atlas dos remanescentes florestais da Mata Atlântica: Período 2012-2013. Relatório técnico. São Paulo: 2014. [acesso em mar. 2015]. Disponível em: http://www.sosma.org.br/wpcontent/uploads/2014/05/atlas_20122013_relatorio_tecnico_20141.pdf.

GANDOLFI, S. História natural de uma floresta semidecidual no município de Campinas (SP. Brasil). 2000. 520f. Tese (Doutorado em Biologia Vegetal) - Universidade Estadual de Campinas, Campinas, 2000.

INSTITUTO BRASILEIRO DE GEOGRAFIA E ESTATÍSTICA - IBGE. Mapa da Vegetação do Brasil escala 1:5. 000.000, $2 \mathrm{ed}$. Rio de Janeiro: IBGE, 1993

LANDIS, J.R.; KOCH, G.G. The measurement of observer agreement for categorical data.

Biometrics. v.33, n.1, p.159-174, 1977.

MACHADO, L. G. Análise da influência da topografia na variação sazonal de fitofisionomias na bacia do Rio Veríssimo - GO. In: SIMPÓSIO

Revista Árvore, Viçosa-MG, v.40, n.5, p.803-813, 2016
BRASILEIRO DE SENSORIAMENTO REMOTO, 2009, Natal. Anais... Natal: INPE, 2009. p.28172822.

MARQUES, O.; TIENNE, L.; CORTINES, E.; VALCARCEL, R. Atributos ambientais definidores de presença de fragmentos florestais de Mata Atlântica em microbacias instáveis. Revista Universidade Rural Série Ciências da Vida, v.24, n.2, p.145-150, 2004.

METZGER, J.P.; MARTENSEN, A.C.; DIXO, M.; BERNACCI, L.C.; RIBEIRO, M.C.; TEIXEIRA, A.M.G.; PARDINI, R. Time-lag in biological responses to landscape changes in a highly dynamic Atlantic Forest region. Biological Conservation, v.142, n.6, p.1166-1177, 2009.

METZGER, J.P. O que é ecologia de paisagens? Biota Neotropica, v.1, n.1-2, p.1-9, 2001.

MYERS, N.; MITTERMEIER, R.A.; MITTERMEIER, C.G.; DAFONSECA, G.A.; KENT, J. Biodiversity hotspots for conservation priorities. Nature, v.403, n.6772, p.853-858, 2000.

RANTA, P.; BLOM, T.O.M.; NIEMELA, J.; JOENSUU, E.; SIITONEN, M. The fragmented Atlantic rain Forest of Brazil: size, shape and distribution of Forest fragments. Biodiversity and Conservation, v. 7, n.3, p.385-403, 1998.

RIBEIRO, L.; PAULO KOPROSKI, L.; STOLLE, L.; LINGNAU, C.; SOARES, R.V.; BATISTA, A.C. Zoneamento de riscos de incêndios florestais para a Fazenda experimental do Canguiri, Pinhais-PR.

Floresta, v.38, n.3, p.561-572, 2008.

RIBEIRO, M.C.; METZGER, J.P.; MARTENSEN, A.C.; PONZONI, F.J.; HIROTA, M.M. The Brazilian Atlantic Forest: How much is left, and how is the remaining forest distributed? Implications for conservation. Biological conservation, v.142, n.6, p.1141-1153, 2009.

RICH, P.M.; DUBAYAH, R.; HETRICK, W.A.; SAVING, S.C. Using Viewshed models to calculate intercepted solar radiation:applications in ecology. American Society for Photogrammetry and Remote SensingTechnical Papers, p.524-529, 1994. 
ROUSE JR, J.; HAAS, R.H.; SCHELL, J.A.; DEERING, D.W. Monitoring vegetation systems in the Great Plains with ERTS. NASA special publication, v.351, p.309, 1974.

SARTORI, A.A.C.; SILVA, R.F.B.; ZIMBACK, C.R.L. Combinação linear ponderada na definição de áreas prioritárias à conectividade entre fragmentos florestais em ambiente SIG. Revista Árvore, v.36, n.6, p.1079-1090, 2012.

SHI, X. ArcSIE user's guide.2013. 111 p. [acessado em: set de 2014]. Disponível em:http:// www.arcsie.com/index.htm
SILVEIRA, C.S.; SILVA, V.V. Dinâmica de regeneração, degeneração e desmatamento da vegetação provocada por parâmetros climáticos e geomorfológicos: uma análise geoecológica através de SIG. Revista Árvore, v.34, n.6, p.1025-1034, 2010.

VALERIANO, M.M. Curvatura vertical de vertentes em microbacias pela análise de modelos digitais de elevação. Revista Brasileira de Engenharia Agrícola e Ambiental, v.7, n.3, p.539-546, 2003.

ZADEH, L.A. Fuzzy sets. Information and control, v.8, n.3, p.338-353, 1965. 